\title{
Effects of Aloe-emodin and Emodin on Proliferation of the MKN45 Human Gastric Cancer Cell Line
}

\author{
Takeshi Chihara ${ }^{1 *}$, Kan Shimpo ${ }^{1}$, Hidehiko Beppu ${ }^{1}$, Naoki Yamamoto ${ }^{2}$, Takaaki \\ Kaneko $^{1}$, Kazumasa Wakamatsu ${ }^{3}$, Shigeru Sonoda ${ }^{1}$
}

\begin{abstract}
Aloe-emodin (1, 8-dihydroxy-3-hydroxyl-methylanthraquinone; AE) and emodin (1,3,8-trihydroxy-6methylanthraquinone; EM) are anthraquinone derivatives that have been detected in some medical plants and share similar anthraquinone structures. AE and EM have been shown to exhibit anticancer activities in various cancer cell lines; however, the inhibitory effects of these derivatives on the growth of cancer cells were previously reported to be different. Gastric cancer is the second most common cause of cancer cell death worldwide. In the present study, we examined the inhibitory effects of $0.05 \mathrm{mM} \mathrm{AE}$ and $0.05 \mathrm{mM}$ EM on the proliferation of the MKN45 human gastric cancer cell line. The proliferation of MKN45 cells was significantly inhibited in AE- and EM-treated groups $24 \mathrm{~h}$ and $48 \mathrm{~h}$ after treatment. Furthermore, the inhibitory effects of EM were stronger than those of AE. The cell cycle of MKN45 cells were arrested in G0/G1 phase or G0/G1 and G2/M phases by AE and EM, respectively. However, an analysis of intracellular polyamine levels and DNA fragmentation revealed that the mechanisms underlying cell death following cell arrest induced by AE and EM differed.
\end{abstract}

Keywords: Aloe-emodin - emodin - MKN45 cells - cell cycle arrest - intracellular polyamines

Asian Pac J Cancer Prev, 16 (9), 3887-3891

\section{Introduction}

The anthraquinone derivatives aloe-emodin (1,8-dihydroxy-3-hydroxyl-methylanthraquinone; $\mathrm{AE})$ and emodin (1,3,8-trihydroxy-6-methylanthraquinone; EM) have been detected in some medicinal plants such as rhubarb (Rheum palmatum) (Huang et al., 2013) and Semen Cassiae (Xu et al., 2012), and share very similar anthraquinone structures (Figure 1).

$\mathrm{AE}$ has been shown to exhibit anticancer activity in various cancer cell lines (Harlev et al., 2012; Suboj et al., 2012a, 2012b; Chen et al., 2014), while EM has also been reported to have anticancer effects on several types of cancer cell lines (Lai et al., 2009; Chun-Guang et al., 2010; Hsu et al., 2010; Wang et al., 2010). Chen et al. (2010) previously demonstrated that the strength of the inhibitory effects of AE and EM on the growth of cancer cells differed.

Gastric cancer is the second most common cause of

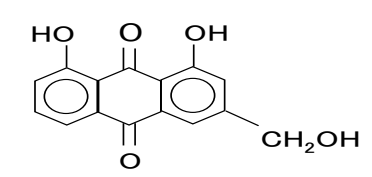

Aloe-Emodin (MW: 270.2)

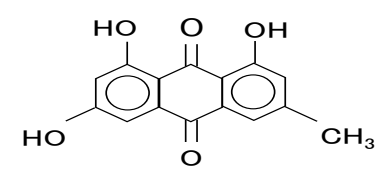

Emodin (MW: 270.2)
Figure 1. Chemical Structures of Aloe-emodin (AE) and Emodin (EM) cancer death worldwide (Yasui et al., 2011). Furthermore, recurrence rates remain high at approximately $70 \%$ following successful surgery (Brenner et al., 2011). Peritoneal dissemination is the most frequent form of recurrent gastric cancer (Shiozaki et al., 2014), and has a poor prognosis. Therefore, the chemoprevention of gastric cancer is required.

Polyamines are low molecular weight biogenic polycationic amines that exist in all living cells. The polyamines putrescine, spermidine, and spermine have been detected in mammalian cells and play important roles in cell growth and differentiation. Polyamine levels were previously shown to increase during cell cycle progression (Seidenfeld et al., 1981). The cell cycle is traditionally divided into four sequential phases (G1, G2, S, and M) and G0: G1, the first gap or growth phase; S, the DNA synthetic phase; G2, the second gap or growth phase; M, the mitotic phase; and G0, the quiescent state. The accumulation and depletion of polyamine levels during cell-cycle progression has been reported (Thomas and Thomas, 2001). Polyamines have been shown to increase in proliferating cells, including tumor cells, but also induce cell death in cancer cells (Thomas and Thomas, 2001).

In the present study, we examined the inhibitory effects of $\mathrm{AE}$ and $\mathrm{EM}$ on the proliferation of the human gastric cancer cell line MKN45 with cell cycle arrest and changes in intracellular polyamine levels.

${ }^{1}$ Division of Biochemistry, Fujita Memorial Nanakuri Institute, Fujita Health University; 423, Oodori-cho, Tsu, Mie, ${ }^{2}$ Laboratory of Molecular Biology \& Histochemistry, Fujita Health University Joint Research Laboratory, ${ }^{3}$ Department of Chemistry, Fujita Health University School of Health Sciences, Toyoake, Aichi, Japan*For correspondence: tchihara@fujita-hu.ac.jp 


\section{Materials and Methods}

Chemicals

AE was purchased from Sigma-Aldrich Co. (Saint Louis, MO, USA). It was dissolved in dimethyl sulfoxide (DMSO) in a stock solution at a concentration of $40 \mathrm{mM}$, stored at $-20^{\circ} \mathrm{C}$, and protected from light. DMSO never exceeded $0.13 \%$ and this concentration did not interfere with growth control cultures. EM was purchased from Fluka Chemie AG (Buchs, Switzerland). It was dissolved in a similar manner to that described for AE.

\section{Cell line and cell culture}

The human gastric cancer cell line MKN45 was kindly provided by Dr. Tadashi Watanabe. Exponentially growing MKN45 cells $\left(2 \times 10^{6}\right)$ were cultured in $25 \mathrm{~cm}^{2}$ plastic flasks containing $4 \mathrm{ml}$ RPMI 1640 (Wako Pure Chemical Industries, Ltd., Osaka, Japan) supplemented with $10 \%$ heat-inactivated fetal bovine serum (Nichirei Biosciences Inc., Tokyo, Japan), 100 units/ml penicillin, and $100 \mu \mathrm{g} /$ $\mathrm{ml}$ streptomycin (Sigma-Aldrich Co.). Cell cultures were maintained at $37^{\circ} \mathrm{C}$ in a humidified atmosphere of $95 \%$ air and $5 \% \mathrm{CO}_{2}$. After being incubated for $24 \mathrm{~h}$, cells were then incubated in a final concentration of $0.05 \mathrm{mM}$ AE or $0.05 \mathrm{mM}$ EM. Control cells cultured in medium containing $0.13 \%$ DMSO. After $24 \mathrm{~h}$ or $48 \mathrm{~h}$ of the AE or EM treatment, the medium was removed and the cell surface was washed once with $4 \mathrm{ml}$ of PBS. Cells were harvested with $0.25 \%$ trypsin in phosphate-buffered saline $\left(\mathrm{Ca}^{2+}\right.$ and $\mathrm{Mg}^{2+}$ free; PBS) with $0.02 \%$ EDTA $-4 \mathrm{Na}$. The cells were pelleted by centrifuging at $1000 \times \mathrm{g}$ for $5 \mathrm{~min}$, and the isolated cells were used in subsequent experiments.

\section{Cell viability assay}

The total number of viable cells was determined at each time point by the trypan blue exclusion test.

\section{Cell cycle analysis}

In the flow cytometry analysis, cells were fixed with $70 \%$ ethanol and then stained with propidium iodide (PI) using a CycleTest Plus DNA Reagent Kit (Becton Dickinson Immunocytometry Systems, San Jose, CA, USA), according to the instructions of the manufacturer, and samples were analyzed by flow cytometry (FACS Vantage SE, Becton Dickinson Immunocytometry Systems). The population of cells in each cell cycle phase was determined with CellQuest ${ }^{\mathrm{TM}}$ software.

\section{Measurement of intracellular polyamine levels}

To analyze intracellular polyamine levels, isolated cells were washed with PBS. Cell pellets were then homogenized in $0.2 \mathrm{M}$ ice-cold perchloric acid solution (PCA), incubated at $4^{\circ} \mathrm{C}$ for $16 \mathrm{~h}$, and the acid-soluble polyamines extracted by centrifugation at $17400 \times \mathrm{g}$ for 10 min. Benzoyl derivatization, which was performed according to the method of Verkoelen et al. (1988), was used to analyze polyamine levels. In this experiment, the benzoyl polyamines, spermidine and spermine were measured by high-performance liquid chromatography with UV detection as described by Verkoelen et al. (1988) with some modifications. Separation was carried out on an Inertsil ODS-2 column (4.6 mm i.d. $\times 150 \mathrm{~mm}, 5 \mu \mathrm{m}$, GL Sciences, Tokyo, Japan) by isocratic elution with $55 \%$ methanol and a flow rate of $1.2 \mathrm{ml} / \mathrm{min}$. Acid-insoluble pellets were dissolved in $0.1 \mathrm{M} \mathrm{NaOH}$ and their protein contents were assayed using the BCA protein assay kit (Pierce Biotechnology Inc., Rockford, IL, USA). Values for spermidine and spermine were reported as nmol/mg protein.

\section{DNA fragmentation analysis}

After $48 \mathrm{~h}$ of the AE or EM treatment, cells were harvested and pelleted according to a previously described method. A DNA fragmentation analysis was performed according to the procedure described by Yanagihara et al. (2005) with minor modifications. Briefly, cell pellets were incubated in lysis solution $[10 \mathrm{mM}$ Tris- $\mathrm{HCl}(\mathrm{pH}$ 7.4), $10 \mathrm{mM}$ EDTA ( $\mathrm{pH} 8.0)$, and $0.5 \%(\mathrm{~V} / \mathrm{V})$ Triton $\mathrm{X}-100]$ at $4^{\circ} \mathrm{C}$ for $15 \mathrm{~min}$. Ribonuclease A $(0.2 \mathrm{mg} /$ $\mathrm{ml}$ ) was added to the lysates, which were incubated at $37^{\circ} \mathrm{C}$ for $1 \mathrm{~h}$, followed by proteinase $\mathrm{K}(0.4 \mathrm{mg} / \mathrm{ml})$ at $50^{\circ} \mathrm{C}$ for $1 \mathrm{~h}$. The lysate was added to $5 \mathrm{M} \mathrm{NaCl}$ and isopropanol and left to stand overnight at $-20^{\circ} \mathrm{C}$ for DNA precipitation. After centrifugation at $17400 \times \mathrm{g}$ for $10 \mathrm{~min}$ at $4^{\circ} \mathrm{C}$, precipitated DNA was dissolved in TE buffer (10 $\mathrm{mM}$ Tris- $\mathrm{HCl}, \mathrm{pH} 7.4,1 \mathrm{mM}$ EDTA) and applied to $2 \%$ agarose gel electrophoresis. The gels were stained with ethidium bromide, and the DNA bands were visualized under ultraviolet light and photographed.

\section{Statistical analysis}

All data were expressed as the mean \pm S.E.M. Statistical analyses were performed using a one-way analysis of variance (ANOVA) followed by Dunnett's multiple comparisons test with InStat version 3.0 for Windows (GraphPad Software, Inc., San Diego, CA, USA).

\section{Results}

\section{Growth inhibitory effects of $A E$ and $E M$}

The results in Table 1 show that the number of viable cells was significantly lower in the AE- and EM-treated groups than in the control group $24 \mathrm{~h}$ and $48 \mathrm{~h}$ after the treatment. Furthermore, the inhibitory effects of EM were stronger than those of AE $24 \mathrm{~h}$ and $48 \mathrm{~h}$ after treatment.

Changes in cell-cycle distribution of MKN45 cells $24 \mathrm{~h}$ after the AE or EM treatment

As shown in Table 2, relative to the control, $0.05 \mathrm{mM}$ AE significantly increased the population of cells in the G0/G1 phase from 53.2 to $63.5 \%$, which was accompanied by a decrease in the proportion of cells in the $S$ phase from 37.1 to $26.7 \%$. This effect was enhanced when MKN45 cells were treated with $0.05 \mathrm{mM}$ EM $(75.2 \%$ of the cell population in the G0/G1 phase and $13.8 \%$ of the cell population in the $\mathrm{S}$ phase). Furthermore, the population of cells in the G2/M phase was significantly increased from 9.8 to $11.1 \%$ by the $0.05 \mathrm{mM}$ EM treatment. These results indicated that the cell cycle of MKN45 cells treated with $0.05 \mathrm{mM}$ AE or $0.05 \mathrm{mM}$ EM was arrested at the G0/G1 phase or $\mathrm{G} 0 / \mathrm{G} 1$ and $\mathrm{G} 2 / \mathrm{M}$ phases, respectively. 
Table 1. Variable Number of MKN45 Cells $24 \mathrm{~h}$ and $48 \mathrm{~h}$ after the AE or EM Treatment

\begin{tabular}{lcc}
\hline Groups & \multicolumn{2}{c}{ Cell number $\left(1 \times 10^{6}\right)$} \\
\cline { 2 - 3 } & $24 \mathrm{~h}$ & $48 \mathrm{~h}$ \\
\hline Control & $4.20 \pm 0.05$ & $4.86 \pm 0.15$ \\
$0.05 \mathrm{mM} \mathrm{AE}$ & $2.93 \pm 0.08^{\mathrm{a}}$ & $1.93 \pm 0.09^{\mathrm{a}}$ \\
& $(30.2)^{\mathrm{b}}$ & $(60.5)$ \\
$0.05 \mathrm{mM} \mathrm{EM}$ & $1.61 \pm 0.04^{\mathrm{a}}$ & $0.32 \pm 0.06^{\mathrm{a}}$ \\
& $(61.7)$ & $(93.4)$ \\
\hline
\end{tabular}

${ }^{\text {aSignificantly different from the cntrol group ( }<<0.01 \text {; Dunnett's multiple }}$ comparisons test). ${ }^{b}$ Numbers in parentheses are the inhibition rates

Table 2. Cell cycle distribution of MKN45 cells $24 \mathrm{~h}$ after the AE or EM treatment

\begin{tabular}{llrr}
\hline \multirow{2}{*}{ Groups } & \multicolumn{3}{c}{ Cell cycle (\%) } \\
& \multicolumn{3}{c}{$24 \mathrm{~h}$} \\
\cline { 2 - 4 } & $\mathrm{G} 0 / \mathrm{G} 1$ & \multicolumn{1}{c}{$\mathrm{S}$} & $\mathrm{G} 2 \mathrm{M}$ \\
\hline Control & $53.2 \pm 0.5$ & $37.1 \pm 0.4$ & $9.8 \pm 0.2$ \\
$0.05 \mathrm{mM} \mathrm{AE}$ & $63.5 \pm 1.8^{\mathrm{a}}$ & $26.7 \pm 1.8^{\mathrm{a}}$ & $9.8 \pm 0.3$ \\
$0.05 \mathrm{mM} \mathrm{EM}$ & $75.2 \pm 1.0^{\mathrm{a}}$ & $13.8 \pm 0.7^{\mathrm{a}}$ & $11.0 \pm 0.5$ \\
\hline
\end{tabular}

a Significantly different from the cntrol group ( $\mathrm{p}<0.01$; Dunnett's multiple comparisons test)

Table 3. Intracellular Polyamine Levels in MKN45 Cells $24 \mathrm{~h}$ and $48 \mathrm{~h}$ after the AE or EM Treatment

\begin{tabular}{lccccc}
\hline Groups & \multicolumn{2}{c}{$24 \mathrm{~h}$} & & \multicolumn{2}{c}{$48 \mathrm{~h}$} \\
\cline { 2 - 3 } \cline { 5 - 6 } & Spd & Spm & & Spd & Spm \\
\hline Control & $9.15 \pm 0.69$ & $7.01 \pm 0.33$ & $12.55 \pm 0.34$ & $7.94 \pm 0.32$ \\
0.05 mM AE & $9.92 \pm 0.55$ & $6.61 \pm 0.26$ & $9.36 \pm 0.79^{\mathrm{a}}$ & $7.45 \pm 0.49$ \\
$0.05 \mathrm{mM}$ EM & $6.55 \pm 0.34^{\mathrm{a}}$ & $6.48 \pm 0.22$ & $7.90 \pm 0.58^{\mathrm{a}}$ & $13.25 \pm 0.48^{\mathrm{a}}$
\end{tabular}

Abbreviations: Spd, spermidine; Spm, spermine; a Significantly different from the cntrol group $(\mathrm{p}<0.01$; Dunnett's multiple comparisons test)

Intracellular polyamine levels of MKN45 cells $24 \mathrm{~h}$ and $48 \mathrm{~h}$ after the $A E$ or EM treatment

The results are shown in Table 3. Spermidine levels $24 \mathrm{~h}$ after the treatment were significantly lower in EMtreated cells than in control cells. Spermidine levels 48 $\mathrm{h}$ after the treatment were significantly lower in AE- and EM-treated cells than in control cells. On the other hand, spermine levels were significantly higher in EM-treated cells than in control cells, whereas no significant difference was observed between AE-treated and control cells.

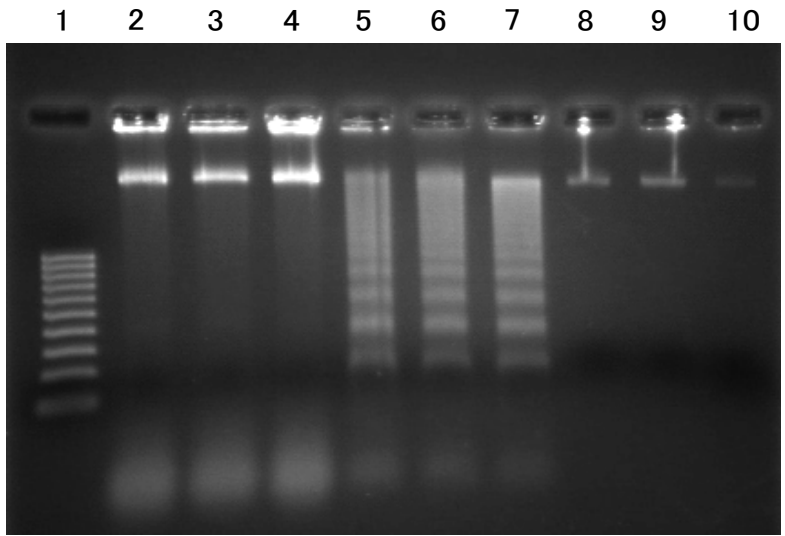

Figure 2. DNA Fragmentation Analysis of MKN45 Cells $48 \mathrm{~h}$ after the AE and EM Treatments. Lane 1, 100bp DNA marker; Lanes 2-4, untreated cells; Lanes 5-7, AE treated cells; Lanes 8-10, EM treated cells
Analysis of DNA fragmentation by agarose gel electrophoresis

Figure 2 shows a DNA fragmentation analysis was used to determine the type of cell death. The control cells showed an intact genome (lanes 2, 3, and 4). However, DNA fragmentation was detected in AE-treated cells (lanes 5, 6, and 7), but was absent in EM-treated cells (lanes 8, 9, and 10).

\section{Discussion}

Chen et al. (2007) previously reported using the gastric cancer cell line AGS that the $\mathrm{IC}_{50}$ value of $\mathrm{AE} 72 \mathrm{~h}$ after the treatment was below $0.07 \mathrm{mM}$. Based on these findings, we examined the inhibitory effects of $0.05 \mathrm{mM}$ $\mathrm{AE}$ and $0.05 \mathrm{mM} \mathrm{EM}$ on the proliferation of the human gastric cancer cell line MKN45. The results obtained clearly demonstrated that AE and EM both significantly inhibited the proliferation of MKN45 cells. Additionally, the inhibitory effects of EM were approximately 2 or 1.5-fold stronger than those of AE $24 \mathrm{~h}$ or $48 \mathrm{~h}$ after the treatment, respectively. Chen et al. (2010) also previously showed that the proliferation of human tongue cancer cell line SCC- 4 was more strongly inhibited by EM than by AE due to the induction of DNA damage and inhibition of DNA repair gene expression. One of the reasons for this difference may be the anthraquinone structure. Badria and Ibrahim (2013) reported that bioactivities were influenced by the position of the hydroxyl group on the anthraquinone structure.

The cell cycle has been divided into four sequential phases (G1, G2, S, and M) and G0. All cells undergo this cell cycle. Cancer has primarily been attributed to the loss of cell cycle regulation (Evan and Vousden, 2001). Therefore, a cell cycle analysis is considered important in the screening of anticancer agents. In the present study, the cell cycle of MKN45 cells treated with $0.05 \mathrm{mM} \mathrm{AE}$ or $0.05 \mathrm{mM}$ EM was arrested at the $\mathrm{G} 0 / \mathrm{G} 1$ phase or $\mathrm{G} 0$ / G1 and G2/M phases, respectively, $24 \mathrm{~h}$ after treatment. Takahashi et al. (2014) showed that metformin, which is a biguanide drug, induced G0/G1 phase arrest after a $24 \mathrm{~h}$ incubation and G0/G1 and G2/M phase arrests after a 48 $\mathrm{h}$ incubation in an endometrial cancer cell line (Ishikawa cell). Based on these findings, they speculated that a low concentration of metformin caused G0/G1 phase arrest, whereas a higher concentration caused $\mathrm{G} 2 / \mathrm{M}$ phase arrest. Lam and $\mathrm{Ng}$ (2010) also found that G0/G1 phase and $\mathrm{G} 2 / \mathrm{M}$ phase arrests occured in a dose-dependent manner in the breast cancer cell line MCF-7 in response to a treatment with haemagglutinin, a carbohydrate-binding protein, $24 \mathrm{~h}$ after the treatment. In the present study, MKN45 cells treated with $0.05 \mathrm{mM}$ EM showed G0/G1 and $\mathrm{G} 2 / \mathrm{M}$ phase arrests. This result was attributed to the stronger inhibitory effects of the $0.05 \mathrm{mM}$ EM treatment than the $0.05 \mathrm{mM}$ AE treatment. A cell cycle analysis may be useful for investigating the model of cell death. Hsiao et al. (2014) showed that pterostilbene, a natural dimethylated analog of resveratrol, simultaneously induced G0/G1 phase arrest and apoptosis in human acute myeloid leukemia cell lines $24 \mathrm{~h}$ after the treatment. Lam 
and $\mathrm{Ng}$ (2010) also reported that a low concentration of haemagglutinin induced G0/G1 phase arrest and the early phase of apoptosis, while a high concentration induced $\mathrm{G} 2 / \mathrm{M}$ phase arrest and a late apoptotic/necrotic stage. In the present study, G0/G1 phase arrest and DNA ladder formation was only observed in the $0.05 \mathrm{mM}$ AE-treated group. AE at a concentration of $0.05 \mathrm{mM}$ may impair the growth of MKN45 cells via G0/G1 phase arrest and concomitant apoptosis.

Regarding intracellular polyamine levels in MKN45 cells $24 \mathrm{~h}$ after the treatment, no significant differences were observed in spermidine levels between the AEtreated group and control group. However, spermidine levels were significantly lower in the EM-treated group than in the control group. Spermine levels were also lower in the AE- and EM-treated group than in the control group. These results are may have been due to cell cycle arrest by the treatment with AE and EM. Ray et al. (1999) showed that the depletion of polyamines lead to cell cycle arrest in normal rat intestinal epithelial cells. On the other hand, regarding intracellular polyamine levels in MKN45 cells $48 \mathrm{~h}$ after the treatment, spermidine levels were significantly lower in both treated groups than in the control group. No significant differences were observed in spermine levels between the AE-treated group and control group, but were significantly higher in the EM-treated group than in the control group. Nemoto et al. (2001) reported that spermine levels were elevated in MKN45 cells treated with DL- $\alpha$-difluoromethylornithine, an inhibitor of polyamine biosynthesis, but did not induce apoptosis. In the present study, DNA ladder formation was not detected in the $0.05 \mathrm{mM}$ EM-treated group. We also analyzed lactate dehydrogenase (LDH) activity in the culture medium $48 \mathrm{~h}$ after the treatment in order to confirm the mechanism responsible for cell death. The results obtained revealed that the $0.05 \mathrm{mM}$ EM treatment induced the release of LDH (data not shown). Necrotic cell death is defined by the breakdown of the plasma membrane, resulting in the leakage of $\mathrm{LDH}$, a cytoplasmic enzyme, from damaged cells (Chan et al., 2013). EM at a concentration of $0.05 \mathrm{mM}$ may impair the growth of MKN45 cells via G0/G1 and G2/M phase arrests and concomitant necrosis.

In conclusion, the $0.05 \mathrm{mM} \mathrm{AE}$ and $0.05 \mathrm{mM} \mathrm{EM}$ treatments significantly inhibited the proliferation of the human gastric cancer cell line MKN45 after $24 \mathrm{~h}$ and 48 $\mathrm{h}$, respectively. Although AE and EM share very similar anthraquinone structures, the inhibitory effects of EM were stronger than those of AE. Furthermore, our results suggested that the mechanisms underlying cell death by $\mathrm{AE}$ and EM differed. We intend to elucidate the molecular mechanisms underlying cell death in more detail in future.

\section{Acknowledgements}

This study was supported in part by a Grant-in-Aid from Fujita Health University.

\section{References}

Badria FA, Ibrahim AS (2013). Evaluation of natural anthracene- derived compounds as antimitotic agents. Drug Discov Ther, 7, 84-9.

Brenner B, Hoshen MB, Purim O, et al (2011). MicroRNAs as a potential prognostic in gastric cancer. World J Gastroenterol, 17, 3976-85.

Chan FK-M, Moriwaki K, De Rosa MJ (2013). Detection of necrosis by release of lactate dehydrogenase (LDH) activity. Methods Mol Biol, 979, 65-70.

Chen R, Zhang J, Hu Y, et al (2014). Potential antineoplastic effects of aloe-emodin: A comprehensive review. Am J Chin Med, 42, 275-88.

Chen S-H, Lin K-Y, Chang C-C, Fang C-L, Lin C-P (2007). Aloe-emodin-induced apoptosis in human gastric carcinoma cells. Food Chem Toxicol, 45, 2296-303.

Chen Y-Y, Chiang S-Y, Lin J-G, et al (2010). Emodin, aloeemodin and rhein induced DNA damage and inhibited DNA repair gene expression in SCC-4 human tongue cancer cells. Anticancer Res, 30, 945-52.

Chun-Guang W, Jun-Qing Y, Bei-Zhong L, et al (2010). Antitumor activity of emodin against human chronic myelocytic leukemia K562 cell lines in vitro and in vivo. Eur J Pharmacol, 627, 33-41.

Evan GI, Vousden KH (2001). Proliferation, cell cycle and apoptosis in cancer. Nature, 411, 342-48.

Harlev E, Nevo E, Lansky EP, Ofir R, Bishayee A (2012). Anticancer potential of aloes: antioxidant, antiproliferative, and immunostimulatory attributes. Planta Med, 78, 843-52.

Hsiao R-C, Chou Y-E, Tan P, et al (2014). Pterostilbene simultaneously induced G0/G1-phase arrest and MAPKmediated mitochondrial-derived apoptosis in human acute myeloid leukemia cell lines. PLoS One, 9, e105342.

Hsu C-M, Hsu Y-A, Tsai Y, et al (2010). Emodin inhibits the growth of hepatoma cells: finding the common anti-cancer pathway using Huh7, Hep3B, and HepG2 cells. Biochem Biophys Res Commun, 392, 473-8.

Huang P-H, Huang C-Y, Chen M-C, et al (2013). Emodin and aloe-emodin suppress breast cancer cell proliferation through ER $\alpha$ inhibition. Evid Based Complement Alternat Med, 2013, 376123.

Lai J-M, Chang J-T, Wen C-L, Hsu S-L (2009). Emodin induces a reactive oxygen species-dependent and ATM-p53-Bax mediated cytotoxicity in lung cancer cells. Eur J Pharmacol, 623, 1-9.

Lam SK, Ng TB (2010). First report of a haemagglutinin-induced apoptotic pathway in breast cancer cells. Biosci Rep, 30, 307-17.

Nemoto T, Kamei S, Seyama Y, Kubota S (2001).p53 independent G1 arrest induced by DL- $\alpha$-difluoromethylornithine. Biochem Biophys Res Commun, 280, 848-54.

Ray RM, Zimmerman BJ, McCormack SA, Patel TB, Johnson LR (1999). Polyamine depletion arrests cell cycle and induces inhibitors $\mathrm{p} 21^{\text {Wafl/Cip1 }}, \mathrm{p} 27^{\mathrm{Kip} 1}$, and $\mathrm{p} 53$ in IEC-6 cells. Am J Physiol, 276, c684-91.

Seidenfeld J, Gray JW, Marton LJ (1981). Depletion of 9L rat brain tumor cell polyamine content by treatment with $\mathrm{D}$, L- $\alpha$-difluoromethylornithine inhibits proliferation and the G1 to S transition. Exp Cell Res, 131, 209-16.

Shiozaki A, Ichikawa D, Takemoto K, et al (2014). Efficacy of a hypotonic treatment for peritoneal dissemination from gastric cancer cells: An in vivo evaluation. Biomed Res Int, 2014, 707089.

Suboj P, Babykutty S, Srinivas P, Gopala S (2012a). Aloe emodin induces $\mathrm{G} 2 / \mathrm{M}$ cell cycle arrest and apoptosis via activation of caspase-6 in human colon cancer cells. Pharmacology, 89, 91-8.

Suboj P, Babykutty S, Valiyaparambil Gopi, et al (2012b). Aloe emodin inhibits colon cancer cell migration/angiogenesis by downregulating MMP-2/9, RhoB and VEGF via reduced 
DNA binding activity of NF-кB. Eur J Pharm Sci, 45, 581-91.

Takahashi A, Kimura F, Yamanaka A, et al (2014). Metformin impairs growth of endometrial cancer cells via cell cycle arrest and concomitant autophagy and apoptosis. Cancer Cell Int, 14, 53.

Thomas T, Thomas TJ (2001). Polyamines in cell growth and cell death: molecular mechanisms and therapeutic applications. Cell Mol Life Sci, 58, 244-58.

Verkoelen CF, Romijn JC, Schroeder FH, van Schalkwijk WP, Splinter TAW (1988). Quantitation of polyamines in cultured cells and tissue homogenates by reversed-phase high-performance liquid chromatography of their benzoyl derivatives. J Chromatogr, 426, 41-54.

Wang W, Sun Y-P, Huang X-Z, et al (2010). Emodin enhances sensitivity of gallbladder cancer cells to platinum drugs via glutathione depletion and MRP1 downregulation. Biochem Pharmacol, 79, 1134-40.

Xu L, Chan C-O, Lau C-C, et al (2012). Simultaneous determination of eight anthraquinones in Semen Cassiae by HPLV-DAD. Phytochem Anal, 23, 110-6.

Yanagihara M, Katano M, Takahashi-Sasaki N, et al (2005). Ribozymes targeting serine/threonine kinase Akt1 sensitize cells to anticancer drugs. Cancer Sci, 96, 620-26.

Yasui W, Sentani K, Sakamoto N, et al (2011). Molecular pathology of gastric cancer: research and practice. Pathol Res Pract, 207, 608-12. 